\title{
EVALUASI PENERAPAN SISTEM MANAJEMEN MUTU ISO 9001:2008 PADA PERGURUAN TINGGI SWASTA (Studi Kasus di Universitas Medan Area)
}

\author{
Yuana Delvika ${ }^{1}$ \\ ${ }^{1}$ Dosen Program Studi Teknik Industri, Fakultas Teknik, Universitas Medan Area \\ Jl. Kolam No. 1 Medan \\ Email : yuana_delvika@yahoo.com
}

\begin{abstract}
Abstrak. Mutu adalah suatu citra yang sangat didambakan oleh setiap perguruan tinggi dalam memberikan jasa kepada pelanggan (mahamahasiswa, alumni, masyarakat dan stakeholder), baik dalam hal jasa pelayanan akademik maupun jasa pelayanan non akademik. Pengertian mutu dalam konteks perguruan tinggi dapat didefinisikan melalui berbagai pendekatan, tetapi pada prinsipnya adalah conformance to requirement, yaitu hasil yang dikerjakan sesuai dengan apa yang diisyaratkan atau yang distandarkan. Universitas Medan Area sebagai suatu perguruan tinggi yang bergerak pada institusi pendidikan telah mendapatkan sertifikat ISO 9001:2008 dan menerapkannya dalam pelaksanaan pelayanan akademik dan non akademik, salah satunya pada lingkup rektorat. Permasalahan yang diangkat adalah bagaimana penerapan standar mutu ISO 9001:2008 dan faktor-faktor apa yang menjadi kendala dalam penerapan standar mutu yang mempengaruhi nilai penerapan ISO 9001:2008 pada lingkup rektorat. Dalam lingkup rektorat tersebut, maka dilakukan wawancara dengan personil yang terkait dan observasi pada pelaksanaan pelayanan tersebut. Penilaian penerapan standar mutu ISO 9001:2008 (klausul 4 sampai dengan klausul 8) ini didapat dengan metode skor audit dan skala pengukuran variabel menggunakan pembobotan dan spider chart. Hasil penelitian dari evaluasi penerapan ISO 9001:2008 adalah ada beberapa klausul yang belum sesuai pada Universitas Medan Area dan kepedapan agar menjadi program prioritas untuk Universitas Medan Area.
\end{abstract}

Keywords: Persediaan, Pengendalian Suku Cadang, Sistem Informasi

\section{Pendahuluan}

Perkembangan teknologi saat ini menimbulkan persaingan yang sangat ketat terutama antara institusi pendidikan sejenis, hal ini mendorong setiap perguruan tinggi untuk dapat memenangkan persaingan yang ada. Berbagai usaha yang menitik beratkan pada kualitas harus dilakukan agar perguruan tinggi dapat mempertahankan diri dan menjadi lebih baik.

Langkah yang dapat diambil dalam usaha mempertahankan pasar yang sudah ada serta usaha untuk mendapatkan pasar yang baru adalah dengan memberikan pelayanan yang terbaik kepada konsumen. Untuk mencapai hal di atas maka digunakan metode sistem manajemen mutu ISO 9001 : 2008 yang sesuai dengan standar internasional. ISO 9001 : 2008 merupakan suatu standar internasional mengenai sistem manajemen mutu yang diakui diseluruh dunia.

Pengimplementasian sistem manajemen mutu ISO 9001 : 2008 yang selama ini dilakukan di Universitas Medan Area harus terus diketahui perkembangannya agar dapat dilihat apakah sistem atau metode tersebut dapat memberikan dampak positif bagi perkembangan perguruan tinggi itu sendiri. Banyak manfaat yang telah diperoleh perguruan tinggi setelah menerapkan sistem manajemen mutu ISO 9001 : 2008 tetapi pihak manajemen belum dapat mengevaluasi klausul yang paling besar diterapkan dan klausul apa yang paling kecil diterapkan, hal ini dianggap perlu agar kedepannya dapat dilakukan perbaikan yang berkelanjutan terhadap penerapan klausul yang paling kecil memberikan pengaruh terhadap kinerja perguruan tinggi.

\subsection{Perumusan Masalah}

Masalah yang diselidiki dalam penelitian ini dapat dirumuskan sebagai berikut :

1. Klausul yang paling besar diterapkan oleh perguruan tinggi setelah menerapkan sistem manajemen mutu ISO 9001 : 2008.

2. Klausul yang paling kecil diterapkan oleh perguruan tinggi setelah menerapkan sistem manajemen mutu ISO 9001 : 2008. 


\subsection{Tujuan dan Sasaran Penelitian}

Adapun tujuan yang ingin dicapai dengan melakukan penelitian ini adalah mengevaluasi klausul yang memberikan manfaat terbesar kepada Universitas Medan Area setelah menerapkan sistem manajemen mutu ISO $9001: 2008$

\subsection{Urgensi Penelitian}

Universitas Medan Area telah menerapkan ISO 9001:2008 dengan biaya investasi yang dikeluarkan cukup besar namun belum jelas manfaat yang diterima dari penerapan setiap klausul. Sehingga hasil yang diperoleh dari penelitian ini lebih objektif. Untuk itu, penelitian ini penting untuk diteliti lebih lanjut.

\section{Metode Penelitian}

Metode penelitian yang digunakan adalah dengan pendekatan action research, yaitu suatu metode yang menyelesaikan suatu indikasi keadaan, gejala pada kondisi yang sudah ada dan sedang berjalan, yang dilakukan dengan pengumpulan data, mentabulasi dan mengklarifikasi serta menginterpretasikan sehingga diperoleh gambaran yang jelas mengenai masalah yang dihadapi dan pada akhirnya usulan pengembangan yang dilakukan.

\subsection{Lokasi Penelitian}

Lokasi penelitian dilakukan pada perguruan tinggi Universitas Medan Area yang terletak dijalan Kolam No.1 Medan.

\subsection{Metode Pengumpulan Data}

Data yang diperlukan dalam penelitian ini dikumpulkan dengan berbagai cara, sebagai berikut:

1. Melakukan observasi langsung, yaitu mencatat sendiri data yang diperlukan yang diperoleh terhadap pengamatan di lapangan.

2. Melakukan Tanya jawab secara langsung dengan pihak yang terkait.

3. Melakukan penelusuran berbagai dokumen yang terkait seperti data masa lalu, kebijakan dan berbagai dokumen yang terkait.

\subsection{Sumber Data}

Data yang diperlukan dalam penelitian ini secara garis besar terdiri dari dua jenis data, yaitu:

\section{Data Primer}

Data Primer meliputi Alur informasi yang ada sekarang dan lain-lain.

\section{Data Sekunder}

Metodologi ini merupakan sesuatu yang sangat penting karena berhasil tidaknya, demikian juga tinggi rendahnya kualitas hasil penelitiannya sangat ditentukan oleh ketetapan penulis dalam memilih metodologi penelitiannya.

Diagram alir atau tahapan-tahapan dalam melakukan dapat ditunjukkan pada Gambar 1 di bawah ini :

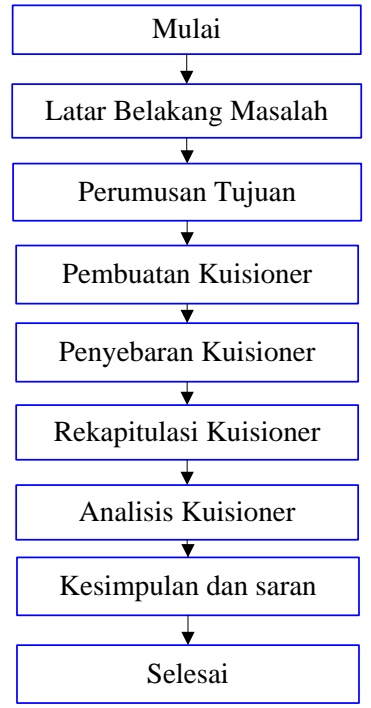

\section{Gambar 1. Diagram Alir Penelitian}

\section{Hasil Penelitian}

Dari rekapitulasi kuisioner di atas dapat dilihat informasi yang diperoleh berdasarkan klausul 4 bahwa klausul 4.2.1, 4.2.2 dan 4.2.4 telah sepenuhnya diterapkan, sedangkan klausul 4.1 dan 4.2.3 belum sepenuhnya diterapkan. Klausul 4.1 yang belum terpenuhi adalah Universitas Medan Area belum pernah melakukan pemantauan, pengukuran dan analisa proses-proses yang terkait untuk menghasilkan kepuasan pelanggan. Universitas Medan Area juga belum menerapkan tindakan - tindakan diperlukan untuk mencapai hasil - hasil yang direncanakan dan peningkatan terus - menerus dari proses - proses ini. Sedangkan analisa dari Klausul 4.2.3 yang belum terpenuhi adalah Universitas Medan Area belum sepenuhnya mencegah penggunaan dokumen - dokumen yang usang atau tidak berlaku lagi dan menerapkan cara identifikasi yang tepat untuk dokumen - dokumen itu apabila masih dipertahankan untuk suatu maksud tertentu. Di unit-unit masih terdapat dokumen yang sudah kadaluarsa masih digunakan dan bahkan unit-unit belum menerima dokumen dengan revisi terakhir. Untuk lebih jelasnya dapat dilihat pada Gambar 2 di bawah ini. 


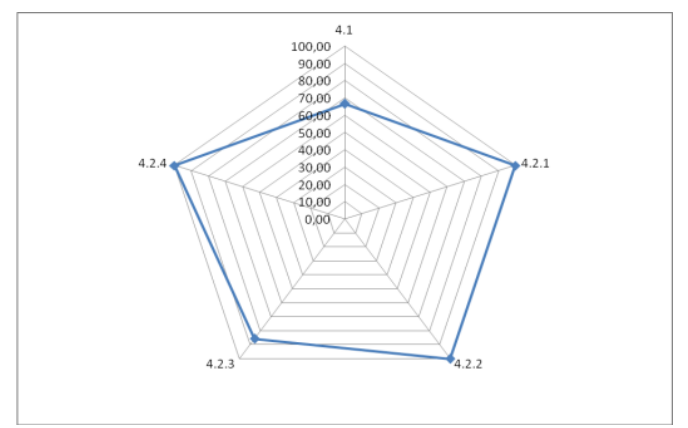

\section{Gambar 2. Spider Chart Penerapan Klausul 4 di Universitas Medan Area}

Untuk klausul 5 hampir semua klausul 5 terpenuhi di Universitas Medan Area. Ini artinya komitmen Top Management sangat baik. Namun klausul 5.4.2 tidak terpenuhi seluruhnya. Hal ini terkait persencanaan yang telah ditetapkan oleh Universitas Medan Area belum mengacu kepada peningkatan terus menerus dari sistem manajemen kualitas yang ada. Perencanaan yang telah dibuat tidak berubah (meningkat) selama 3 tahun terakhir. Dan tidak ada integritas dari Sistem Manajemen Kualitas agar tetap terpelihara apabila perubahan perubahan dari Sistem Manajemen itu direncanakan dan diimplementasikan. Untuk lebih jelasnya dapat dilihat pada Gambar 3 di bawah ini.

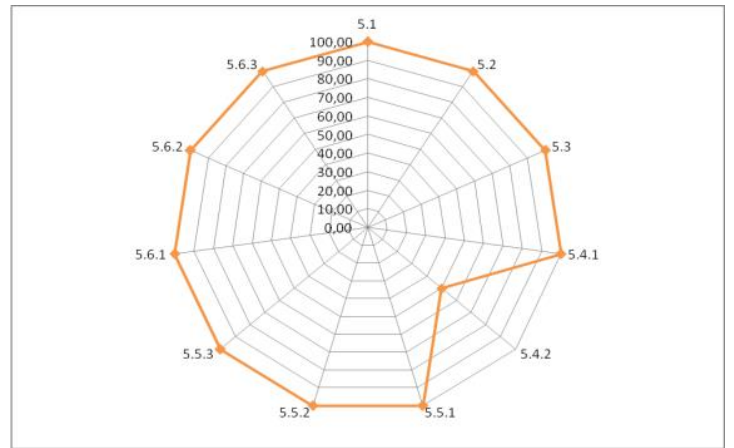

\section{Gambar 3. Spider Chart Penerapan Klausul 5 di Universitas Medan Area}

Klausul 6 terkait dengan klausul sumber daya, baik sumber daya manusia, sarana prasarana dan lingkungan kerja. Universitas Medan Area telah sepenuhnya menerapkan klausul 6 ini. Untuk lebih jelasnya dapat dilihat pada Gambar 4 di bawah ini.

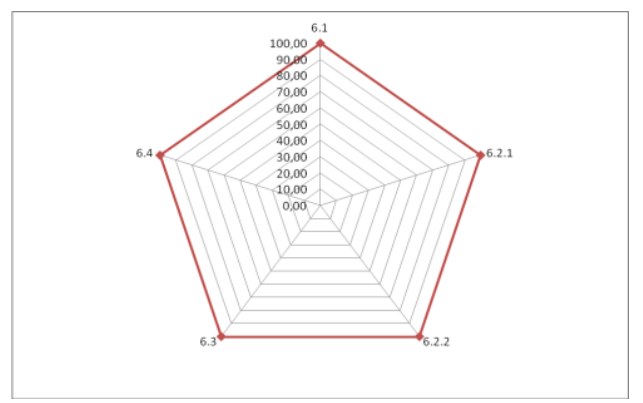

\section{Gambar 4. Spider Chart Penerapan Klausul 6 di Universitas Medan Area}

Klausul 7 berisi tentang kegiatan operasional khususnya untuk perancangan kurikulum, belajar mengajar, praktikum, monitoring proses belajar mengajar dan proses wisuda. Universitas Medan Area telah konsisten sepenuhnya menerapkan hampir semua klausul 7 namun ada 2 klausul yang belum sepenuh nya diterapkan yaitu klausul 7.2.2 dan klausul 7.6. Klausul 7.2.2 menetapkan bahwa organisasi harus melaksanakan peninjauan ulang seluruh persyaratan yang dibutuhkan oleh pelanggan dan stakeholder. Universitas Medan Area telah melaksanakan peninjauan ulang tersebut tetapi proses peninjauan-ulang belum menjamin bahwa perubahan persyaratan - persyaratan produk telah dilakukan dan disadari oleh personel yang relevan dalam organisasi. Hasil - hasil peninjauanulang dan tindakan - tindakan yang berkaitan juga belum didokumentasikan dan dipelihara.

Untuk klausul 7.6 menetapkan organisasi harus melaksanakan pemantauan pengukurang yang dilaksanakan. Universitas Medan Area belum melakukan kalibrasi dan verifikasi secara periodik atau sebelum digunakan terhadap alat yang memiliki standar nasional atau internasional. Jika tidak ada standar kalibrasi yang sesuai, maka landasan yang digunakan untuk kalibrasi ini harus dicatat dan dipelihara. Universitas Medan Area juga belum menjaga alat dari kerusakan dan penurunan keandalan (kemerosotan) selama penanganan, pemeliharaan dan penyimpanan alat tersebut. Untuk lebih jelasnya dapat dilihat pada Gambar 5 di bawah ini.

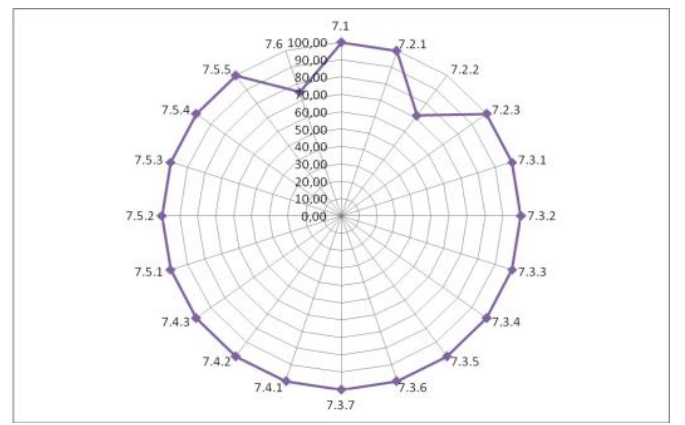

Gambar 5 Spider Chart Penerapan Klausul 7 di Universitas Medan Area 
Klausul 8 menetapkan organisasi diwajibkan melakukan pengukuran dan pemantauan kinerja sistem yang telah ditetapkan sebelumnya. Universitas Medan Area telah melaksanakan pengukuran dan pemantauan tersebut namun ada beberapa klausul yang belum terpenuhi antara lain klausul 8.2.3 pemantauan proses telah dilaksanakan tetapi apabila hasil - hasil yang direncanakan tidak tercapai maka tindakan korektif belum dilakukan untuk perbaikan. Pada klausul 8.3 Universitas Medan Area telah mengelola ketidaksesuaian namun proses - proses yang dirancang belum menjamin bahwa produk yang tidak sesuai dengan persyaratan diidentifikasi dan dikendalikan untuk mencegah dari penggunaaan yang tidak diinginkan atau penyerahaan kepada pelanggan. Ketidaksesuaian tersebut juga belum diperbaiki ulang, apakah hasil perbaikan ulang itu diverifikasi kembali agar menjamin kesesuaian terhadap persyaratan produk.

Klausul 8.5.3 tentang tindakan preventif (tindakan pencegahan) sepenuhnya belum diterapkan oleh Universitas Medan Area. Universitas Medan Area telah membuat prosedur tertulis untuk tindakan pencegahan. Namun saat ini belum mengidentifikasi ketidaksesuaian potensial dan penyebab - penyebabnya, belum mengevaluasi kebutuhan untuk tindakan pencegahan terjadi ketidaksesuaian, belum mencatat hasil - hasil dari tindakan preventif yang dilakukan, belum meninjau-ulang efektivitas dari tindakan preventif yang dilakukan dan tindakan preventif yang dilakukan itu belum menghilangkan penyebab penyebab potensial dari ketidaksesuaian yang berpengaruh pada masalah - masalah potensial. Untuk lebih jelasnya dapat dilihat pada Gambar 6 di bawah ini.

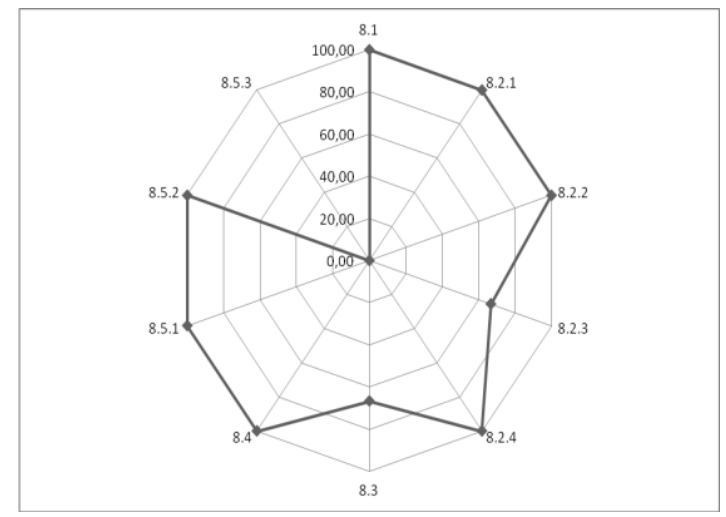

Gambar 6. Spider Chart Penerapan Klausul 8 di Universitas Medan Area

\section{Kesimpulan}

Kesimpulan dari penelitian ini adalah sebagai berikut :
1. Klausul 4 bahwa klausul 4.2.1, 4.2.2 dan 4.2.4 telah sepenuhnya diterapkan, sedangkan klausul 4.1 dan 4.2 .3 belum sepenuhnya diterapkan. Klausul 4.1 yang belum terpenuhi adalah Universitas Medan Area belum pernah melakukan pemantauan, pengukuran dan analisa proses-proses yang terkait untuk menghasilkan kepuasan pelanggan. Universitas Medan Area juga belum menerapkan tindakan - tindakan diperlukan untuk mencapai hasil - hasil yang direncanakan dan peningkatan terus - menerus dari proses - proses ini. Sedangkan analisa dari Klausul 4.2.3 yang belum terpenuhi adalah Universitas Medan Area belum sepenuhnya mencegah penggunaan dokumen - dokumen yang usang atau tidak berlaku lagi dan menerapkan cara identifikasi yang tepat untuk dokumen - dokumen itu apabila masih dipertahankan untuk suatu maksud tertentu. Di unit-unit masih terdapat dokumen yang sudah kadaluarsa masih digunakan dan bahkan unitunit belum menerima dokumen dengan revisi terakhir.

2. Klausul 5 hampir semua klausul 5 terpenuhi di Universitas Medan Area. Ini artinya komitmen Top Management sangat baik. Namun klausul 5.4.2 tidak terpenuhi seluruhnya. Hal ini terkait persencanaan yang telah ditetapkan oleh Universitas Medan Area belum mengacu kepada peningkatan terus menerus dari sistem manajemen kualitas yang ada. Perencanaan yang telah dibuat tidak berubah (meningkat) selama 3 tahun terakhir. Dan tidak ada integritas dari Sistem Manajemen Kualitas agar tetap terpelihara apabila perubahan perubahan dari Sistem Manajemen itu direncanakan dan diimplementasikan.

3. Klausul 6 terkait dengan klausul sumber daya, baik sumber daya manusia, sarana prasarana dan lingkungan kerja. Universitas Medan Area telah sepenuhnya menerapkan klausul 6 ini.

4. Klausul 7 berisi tentang kegiatan operasional khususnya untuk perancangan kurikulum, belajar mengajar, praktikum, monitoring proses belajar mengajar dan proses wisuda. Universitas Medan Area telah konsisten sepenuhnya menerapkan hampir semua klausul 7 namun ada 2 klausul yang belum sepenuh nya diterapkan yaitu klausul 7.2.2 dan klausul 7.6. Klausul 7.2.2 menetapkan bahwa organisasi harus melaksanakan peninjauan ulang seluruh persyaratan yang dibutuhkan oleh pelanggan dan stakeholder. Universitas Medan Area telah melaksanakan 
peninjauan ulang tersebut tetapi proses peninjauan-ulang belum menjamin bahwa perubahan persyaratan - persyaratan produk telah dilakukan dan disadari oleh personel yang relevan dalam organisasi. Hasil - hasil peninjauan-ulang dan tindakan - tindakan yang berkaitan juga belum didokumentasikan dan dipelihara. Untuk klausul 7.6 menetapkan organisasi harus melaksanakan pemantauan pengukurang yang dilaksanakan. Universitas Medan Area belum melakukan kalibrasi dan verifikasi secara periodik atau sebelum digunakan terhadap alat yang memiliki standar nasional atau internasional. Jika tidak ada standar kalibrasi yang sesuai, maka landasan yang digunakan untuk kalibrasi ini harus dicatat dan dipelihara. Universitas Medan Area juga belum menjaga alat dari kerusakan dan penurunan keandalan (kemerosotan) selama penanganan, pemeliharaan dan penyimpanan alat tersebut.

5. Klausul 8 menetapkan organisasi diwajibkan melakukan pengukuran dan pemantauan kinerja sistem yang telah ditetapkan sebelumnya. Universitas Medan Area telah melaksanakan pengukuran dan pemantauan tersebut namun ada beberapa klausul yang belum terpenuhi antara lain klausul 8.2.3 pemantauan proses telah dilaksanakan tetapi apabila hasil - hasil yang direncanakan tidak tercapai maka tindakan korektif belum dilakukan untuk perbaikan. Pada klausul 8.3 Universitas Medan Area telah mengelola ketidaksesuaian namun proses - proses yang dirancang belum menjamin bahwa produk yang tidak sesuai dengan persyaratan diidentifikasi dan dikendalikan untuk mencegah dari penggunaaan yang tidak diinginkan atau penyerahaan kepada pelanggan. Ketidaksesuaian tersebut juga belum diperbaiki ulang, apakah hasil perbaikan ulang itu diverifikasi kembali agar menjamin kesesuaian terhadap persyaratan produk. Klausul 8.5.3 tentang tindakan preventif (tindakan pencegahan) sepenuhnya belum diterapkan oleh Universitas Medan
Area. Universitas Medan Area telah membuat prosedur tertulis untuk tindakan pencegahan. Namun saat ini belum mengidentifikasi ketidaksesuaian potensial dan penyebab penyebabnya, belum mengevaluasi kebutuhan untuk tindakan pencegahan terjadi ketidaksesuaian, belum mencatat hasil - hasil dari tindakan preventif yang dilakukan, belum meninjau-ulang efektivitas dari tindakan preventif yang dilakukan dan tindakan preventif yang dilakukan itu belum menghilangkan penyebab - penyebab potensial dari ketidaksesuaian yang berpengaruh pada masalah - masalah potensial

\section{DAFTAR PUSTAKA}

Gasperz, Vincent. 2002. ISO 9001:2000 and Continual Quality Improvement. Jakarta : PT. Gramedia Pustaka Utama.

Gasperz, Vincent, 2012, Three-in-One ISO-9001, ISO-14001, OHSAS-18001, Contoh Aplikasi pada Bisnis dan Industri, Vinchristo Publication

Harbubagin, B dan Ronitua, P. 1995. 26 Langkah Menuju Sertifikasi ISO 9000. Jakarta : PT. Iron Damwin Sentosa.

Santosa, Made Arya Wira, Penerapan Sistem Manajemen Mutu ISO 9001:2008, Jurnal Ilmiah Elektronik Infrastruktur Teknik Sipil, Vol 2, No.1 Pebruari 2013.

Wartiningsih, Endah. Evaluasi Penerapan Sistem Manajemen Mutu di Politeknik xxx, Jurnal Epigram, Vol.10, No.2 Oktober 2014.

Tjiptono, F dan Diana A. 2001. Total Quality Management. Yogyakarta : Penerbit Andi. 2010, Sistem Penjaminan Mutu Perguruan Tinggi (SPM-PT), Depdiknas, Ditjen Dikti

,2008, Kompilasi Buku Penjaminan, Sistem Penjaminan Mutu Perguruan Tinggi SPM-PT, KKM-IPB.

2012, Pedoman Mutu-ISO-9001:2008 Universitas Medan Area, Lembaga Penjamin Mutu 